\title{
Cervix Squamous Epithelium
}

National Cancer Institute

\section{Source}

National Cancer Institute. Cervix Squamous Epithelium. NCI Thesaurus. Code C49219.

The epithelium of the ectocervix, which consists of nonkeratinized, stratified squamous cells. 